wellingtoncitylibraries/docs/jacquie_baxter-jc _ sturm_biography?e=37768242/75276900

29. Evans, Marian; Lonie, Bridie; Lloyd, Tilly (eds). A Women's Picture Book: 25 Women Artists of Aotearoa (New Zealand). GP Books, 1988, p 30

30. Pauline was not the only woman experiencing these challenges to her art process and sense of self as a woman expected to perform gendered tasks to fit a gendered model of heterosexual households. Te Papa holds a collection of interviews with 50 women artists created in the 1980s who 'represented the burgeoning women's art movement in New Zealand', affilited with the Association of Women Artists. This colloction Association of Women Artists. This collection was made possible by artist, teacher, and feminist Vivian Lynne...who volunteered to collect those interviews. Lynne herself 'began questioning the roles women were expected to play in society [during the 1960s] as wives and mothers, and in the art world, as secondary to their male peers'. https://collections. tepapa.govt.nz/object/189

31. In 1997 in an exhibition catalogue for a solo exhibition of Pauline's work at Whangare Art Gallery, Megan Corbett wrote that Thompson 'worked in a Pop Art idiom in conjunction with her 'wurkery a Pop Ant idiom in conjun husband. After the break up of this relationship her work took a more serious and metaphysical aspect Megan Corbett, 'Pauline Thompson: Tuki \& Huru Suite - Banner Paintings'. Whangarei Art Museum newsletter Dec 1997 no.5

32. For example Stewart, Keith. The Food of Art: New Zealand Painters and their food. Craig Potton Publishing, 2000; Brown, Warwick. 100 New Zealand Paintings. Godwit, 1995; Brown, Warwick. Another 100 New Zealand Artists. Godwit, 1996.

33. Warwick Brown, 100 New Zealand Paintings, Godwit, 1995, p. 89.

34. In his follow up book for 1996 'Another 100 New Zealand Painters', 29 of the painters are women. Brown, Warwick. Another 100 New Zealand Artists. Godwit, 1996.

35. Te Miringa Hohaia, Gregory O'Brien, Lara Strongman (eds) Parihaka: The Art of Passive Resistance. City Gallery Wellington, Victoria University Press, 2001, p 165.

36. O'Brien's newest publication A/ways Song in the Water: An Oceanic Sketchbook, Gregory O'Brien AUP, 2019 has a section on Pauline's work.
37. Miriam Macgregor, Petticoat Pioneers. North Island Women of the Colonial Era, Book One A.H.and A.W.Reed, Wellington and Christchurch, first published 1973, 1978 (second edition), 1981 (third edition).

38. Evans, Marian; Lonie, Bridie; Lloyd, Tilly (eds). A Women's Picture Book: 25 Women Artists of Aotearoa (New Zealand) GP Books, 1988. p.34.

$$
\text { 39. Jessie Munro, The Story of Suzanne Aubert, }
$$
Bridget Williams Books, 1996 (first edition).

40. Letter to Sister Josephine 28 March 2010 from Pauline Thompson, Anne McLean Dr, Bayview, North Shore Auckland in Home of Compassion archives, Island Bay Wellington, Pauline Thompson 20090040010 (2001-2009).

41. Pauline Thompson to Sr Josephine Gorman and Sisters at the Home of Compassion, 28 March 2010, Home of Compassion Archive Island Bay Wellington, Pauline Thompson 20090040010 (2001-2009).

42. Wendy Vaigra, 'Narratives of the Heart: Recent Paintings by Pauline Thompson', Art New Zealand No. 59 Winter 1991 p.71.

43. Letter to Sister Josephine 28 March 2010 from Pauline Thompson, Anne McLean Dr, Bayview, North Shore Auckland, Home of Compassion Archive Island Bay Wellington, Pauline Thompson 20090040010 (2001-2009).

44. Keith Stewart, The Food of Art; New Zealand Painters and their food, Craig Potton, 2000 p.114

45. Stewart, K. ibid p.114

46. Stewart, Keith, p.116

47. John Kelly, correspondence with author, 2 June 2017

48. Wendy Vaigro, 'Narratives of the Heart: Recent Paintings by Pauline Thompson' Art New Zealand No.59 Winter 1991, p.71

49. Evans, Marian; Lonie, Bridie; Lloyd, Tilly (eds). A Women's Picture Book: 25 Women Artists of Aotearoa (New Zealand). GP Books, 1988, p.31

\section{Self Help, Sunlight and a Modern Chair: Considering Auckland's historic signage as a heritage object}

Caroline Powley

Cities are an ever-changing space, filled with commerce and community. Signage plays a strong role in the visual narrative of the urban environment. It creates a constant visual hum, a street level monologue of promotion, identification and direction. Commercial signs are designed to serve and improve business. So, what role could an old, fading or non-functioning piece of signage possibly play in our neoliberal capitalist society? From a designer's perspective, there's a lot to like - the craftsmanship, the idiosyncrasies of a hand-generated piece of typography, the sense of nostalgia for a time before globalisation and brand guidelines took over. Looking at historic signs from a broader context they also represent an "intricate urban history." 1 They speak of the changing face of commercial enterprise, social values and cultural expression. Even when they no longer serve their original semantic role of commercial promotion, they "accumulate rich layers of meaning. They no longer merely advertise, they are valued in and of themselves. They become icons." 2 The semiotic function of an historic sign shifts to a new role-signifying notions of survival, continuity and loss. They also feed into our complex personal narratives of place, identity and community. ${ }^{3}$ These multiple and interwoven values can form the cultural significance of historic signs. Despite this recognisable value, historic signage tends to fall through the gaps of heritage practice and legislation in New Zealand. This paper offers a set of case studies that represent a range of possible outcomes for historic signs, when they exist outside a system of heritage management. I propose six categories for framing the case studies: remain, repair, regenerate, relocate, replace and remove. These examples are combined with a broader reflection on the value of historic signage and an overview of relevant heritage practice in New Zealand. The intention is to encourage reflection on the possible heritage significance of historic signage and our current approach to assessment, scheduling and conservation.

Keywords: \#signage \#heritage \#historic places \#preservation \#cultural value 
Signage forms a key part of the urban semioscape-it communicates information and enticement, while also reflecting the surrounding society and culture. Historic signs represent the ebb and flow of commerce-they speak of long-gone products and businesses, while providing insight into the evolution of capitalism. Early in the $20^{\text {th }}$ century signage was often unique to a particular shop and location-allowing for a level of cultural specificity. ${ }^{4}$ Coppoolse and Kwok suggest that local neon signage has the ability to tell stories that not only 'speak' consumption but to also 'speak' Hong Kong. ${ }^{5}$ The rise of a globalised economy and large corporations has meant that generationally-owned small family businesses have begun to make way for franchises and multinational chains. ${ }^{6}$ As Baines and Dixon suggest, "nothing eradicates a sense of locality more than the consistent promotion of an [corporate] identity." This is not merely a nostalgic notion that historic signs are from a more 'innocent' era of capitalism. The shift from idiosyncratic variety towards ubiquitous uniformity reflects a lost opportunity for the expression of local cultural identity.

Huyssen identifies our need for "spatial and temporal anchoring in a world of increasing flux in ever denser networks of compressed space and time." 8 By acting as a point of distinctive character for a local area, historic signs can function as landmarks that help us build our internal representations of the familiar, built environment. ${ }^{9}$ These cognitive maps contribute to our sense of place, community, and personal identity. ${ }^{10}$ Historic signs can also reinforce these connections, by signifying a sense of continuity through time. By reflecting a localised and often culturally specific history, historic signs allow people to feel part of an ongoing community and social narrative.

Another human connection is formed by seeing something so clearly handmade in a commercial space. Baudrillard suggests that "the fascination of handicraft derives from an object's having passed through the hands of someone the marks of whose labour are still inscribed thereupon." 11 A piece of hand-painted type unevenly aligned to a baseline of bricks brings a reassuring sense of humanity to an increasingly standardised and slick urban environment. The ability of a signwriter to adapt a design to a specific site also brings a sense of responsiveness to context that stands in contrast to the surface application of adhesive vinyl that has been printed offsite. Laser-cut plastic signage can offer little of the beauty of gold leaf on glass or the rich depth of colour of pigment in paint. Mastery of these traditional materials has dramatically reduced, as the skilled craft of hand-generated signwriting gave way to the rapid uptake of a digital design and production process. Historic signs therefore signify the erosion of both time and craft. $^{12}$

By narrowly surviving the best efforts of climate, gentrification and globalisation to destroy them, historic signs manifest as a "metaphor for survival." ${ }^{13}$ Conversely the slow physical decline of materials - the flaking of paint, the decay of wood-can represent the precarious nature of existence. This dialectic narrative of survival and loss may create some of a historic signs resonance, while also hinting at the difficulties of situating it within heritage management.

HERITAGE

Heritage has been described as a 'capricious' and 'nomadic' term that represents "an unstable and contested idea." 14 In its most basic form, heritage practice deals with "things of value, which are inherited." ${ }^{15}$ The 2010 New Zealand Charter of the International Council on Monuments and Sites (ICOMOS) describes 'cultural heritage value' as "treasures of distinctive value that have accrued meaning over time." 16 The means of identifying, assessing and managing these taonga in Aotearoa is a complex system involving multiple organisations and legislation. Heritage New Zealand Pouhere Taonga (HNZPT), the Department of Conservation (DOC) and the local authorities are largely responsible for the formal registering and management of New Zealand heritage. The two key pieces of legislation are the Resource Management Act (RMA 1991) and the Heritage New Zealand Poutere Taonga Act (HNZPTA 2014). Both provide for identification and protection of heritage, but at different levels and to different degrees. The focus of HNZPT on a national context of significance and the lack of resources to identify locally significant heritage means there are gaps in identification and protection. ${ }^{17}$ Given the complex heritage landscape, it is understandable that historic signage has largely fallen through these gaps between various organisations, legislation and scheduling lists.

Heritage New Zealand Pouhere Taonga (HNZPT) is an autonomous Crown Entity and its primary function is to "identify, record, investigate, assess, list, protect, and conserve historic places, historic areas, wāhi tūpuna, wāhi tapu, and wāhi tapu areas..."18 It does this through fostering public interest and involvement in historic places and historic areas and advocating for their conservation and protection. ${ }^{19}$ HNZPT also maintains the New Zealand Heritage List/Rārangi Kōrero ('the List'). This "informs and notifies owners, the public, community organisations, government agencies and local authorities about significant heritage 
places" and is a source of information about New Zealand's heritage "for the purposes of the Resource Management Act 1991."20 When assessing the significance of a possible heritage subject HNZPT use a set of criteria that look for aesthetic, archaeological, architectural, cultural, historical, scientific, social, spiritual, technological or traditional qualities. ${ }^{21}$ When I spoke to Andrew Winter from HNZPT in March 2018, he suggested that historic signage could possibly fall under three of the assessment criteria-historical ("reflects a trend that had an impact on New Zealand history"), cultural ("provides insight into the culture of a community") or aesthetic ("outstanding or famous visual attributes"). ${ }^{22}$ He couldn't recall any signage being specifically identified in the List, but directed me to a listing for the Strong's Watchmaker shop in Naseby. ${ }^{23}$
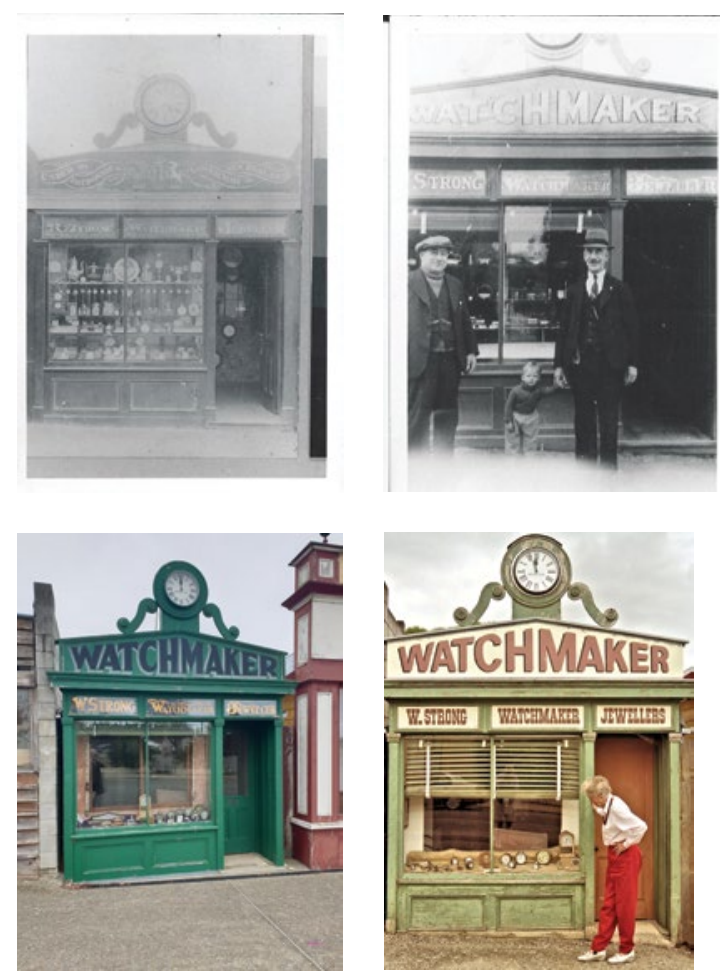

1. Unknown. G. Strong Watchmakers, Naseby, Otago, ca. 1890, Naseby, Central Otago ( ) All rights reserved, Maniototo Early Settlers Museum. 2. Unknown. G. Strong Watchmakers, Naseby, Otago, 1938, Naseby, Central Otago. C All rights reserved, Maniototo Early Settlers
Museum. 3. Maryann Devereux, Watchmaker's store, 2018. Naseby, Otago. @ All rights Museum. 3. Maryann Devereux, Watchmaker's store, 2018, Naseby, Otago. ๑ All rights reserved, Maryann Devereux. 4. David Green, Watchmaker's store, 2018, Naseby, Otago. ๑) All rights reserved, David Green.
This watchmakers shop was built in the late 1860s, during the gold rush in Central Otago and has Category 1 scheduling in the Heritage List/ Rārangi Kōrero ('the List'). ${ }^{24}$ The assessment criteria information about this listing mentions the decorative and ornate façade but does not specifically refer to the hand-painted signage, despite it being a primary visual feature of the building's exterior. ${ }^{25} \mathrm{~A}$ level of disregard for its significance and design qualities can be seen in the recent repainting of the signage. The insensitive typographic treatment includes poor scaling and kerning on the sans serif capitals, along with a strangely tiny drop shadow. The choice of a heavy slab serif for the smaller text may be an attempt at referencing the 'gold-rush' era of the store, but this American 'Wild West' aesthetic bears no resemblance to any of the typography seen in historic photos of the shopfront. These images show multiple reworkings of the design - a common practice in the past that now creates complications for any attempt at contemporary conservation. The ICOMOS NZ charter states that preservation should involve as little intervention as possible and any alterations should be compatible with the original form and avoid inappropriate or incompatible contrasts of form, scale, mass, colour, and material. ${ }^{26}$ While it is clearly difficult to define what the 'original form' might be in this case, the recent repainting fails to conserve any of the signage's possible historic design references, despite the sites Category 1 listing.

Making it onto HNZPT's list is not the only way to formally recognise the significance of our cultural heritage. It is also worth noting that the List does not guarantee protection or "directly create regulatory consequences or legal obligations on property owners". Instead the "real teeth of heritage protection" sits in the Resource Management Act (RMA) and is administered by local authorities through their District Plans and heritage schedules. ${ }^{27}$ The Auckland Unitary Plan states the need to "avoid significant adverse effects", including the "total or substantial demolition or destruction" or "relocation or removal" of the primary features of scheduled significant historical heritage places. ${ }^{28}$ The Auckland Council facilitates this by maintaining a Historic Heritage Schedule-anything included is "protected by provisions in the plan to ensure its significance is not lost." ${ }^{29}$ When I spoke to Tanya Sorrell, who was in the Auckland Council Heritage Team, she said that, "the rules in the plan are not set up well to protect historic signage on its own, particularly when it is attached to a building that doesn't qualify for scheduling. Historical signs can easily lose their integrity through neglect as well, meaning an inability to require proactive maintenance under the RMA makes protecting this kind of heritage a struggle." 30 


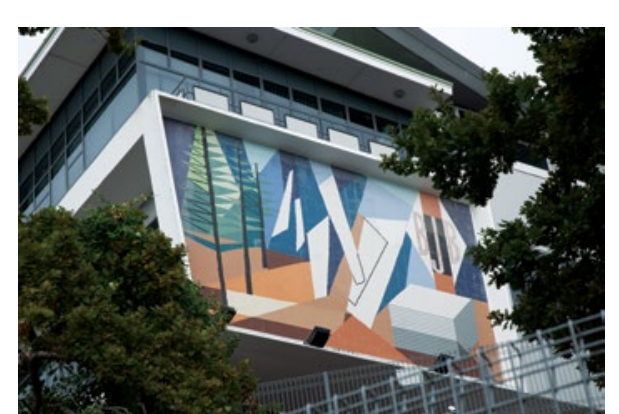

5. Caroline Powley, BJ Ball mural, 2018, 35 Graham Street, Auckland Central.

While the Auckland Council Heritage Team were aware of several historic signs, they noted that the only currently scheduled item that clearly related to signage is the BJ Ball mural. This large mural was commissioned in 1958 by BJ Ball (a paper manufacturer) for the side of their central Auckland office building. ${ }^{31}$ It was designed by Milan Mrkusich, one of New Zealand's most highly respected abstract artists. ${ }^{32}$ It is constructed from thousands of glass and ceramic tiles, crafted in Italy and shipped to NZ for installation. ${ }^{33}$ The exterior of the entire building currently has Category B scheduling, which acknowledges the site has considerable overall heritage significance to the locality or greater geographic area. ${ }^{34}$ This means the site should be protected from "inappropriate subdivision, use and development, including inappropriate modification, relocation, demolition or destruction." 35 While the scheduling of this piece as part of the building's exterior shows what is possible, it must be noted that it is distinct from what might ordinarily be classified as purely 'commercial signage' in several ways. It is largely abstract in design, more robust in its materials and created by a well-established artist.

\section{CASE STUDIES}

In 2004, I made an informal survey of hand-generated signs in Auckland. I took over 1000 photos of signage, ranging from dairy signs through to gilded pub windows. I focussed largely on 'historic' signs, which I arbitrarily defined as over 20 years old. The signs were diverse in materials and site placement. Some are still 'active' as they promote a business, service or product that is still available or operating today.

Over the last 16 years a significant number of these signs have experienced some form of alteration and I have continued to document their fate. On review of this ongoing photographic archive, I identified a set of twelve case studies that suggested a system of categorisationremain, repair, regenerate, relocate, replace and remove. These proposed categories offer a framework for mapping what can happen to a historic sign when it is not proactively protected. They fall into three groupings that reflect the broader outcomes - 'HERE' where the signs have stayed in their original locations, 'TRACE' where some aspect of the sign continues on and 'GONE' where the signs no longer physically exist. None of these categories directly suggests heritage assessment or management strategies. However, this paper hopes to prompt reflection on the cultural significance of historic signs and encourage an increased amount of scheduling and protection.

\section{HERE-Remain / Repair \\ TRACE-Regenerate / Relocate \\ GONE-Replace / Remove}

HERE-REMAIN

It may seem that the obvious best option for a historic sign is for it to remain in its existing place and context. However, there are several factors that may complicate this immediate solution.

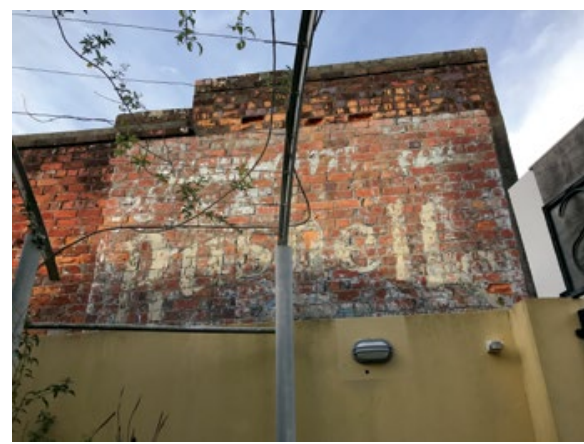

6. Robert Powley, Bushel/s sign, 2018, Devonport, Auckland.

On a practical level, there can be issues with leaving the sign exposed to ongoing environmental impact. Part of the aesthetic appeal of vintage signs is often the signs of visible wear that indicate the passing of time. However, these signifiers of antiquity can easily slip into the total loss of the sign. If nature is left to take its course, some signs will crack, peel or rot away entirely.

Leaving a sign in situ when it refers to a business that is no longer active, can also raise a number of issues. This can be particularly 
problematic if the signage is analogous with a proposed new use of the building. Signs exist in a commercial space-they are created to communicate a quite specific and often singular message. New businesses moving in to a building with a historic sign painted on it, may be concerned about mixed messages, brand clarity or a negative effect on commercial outcomes.

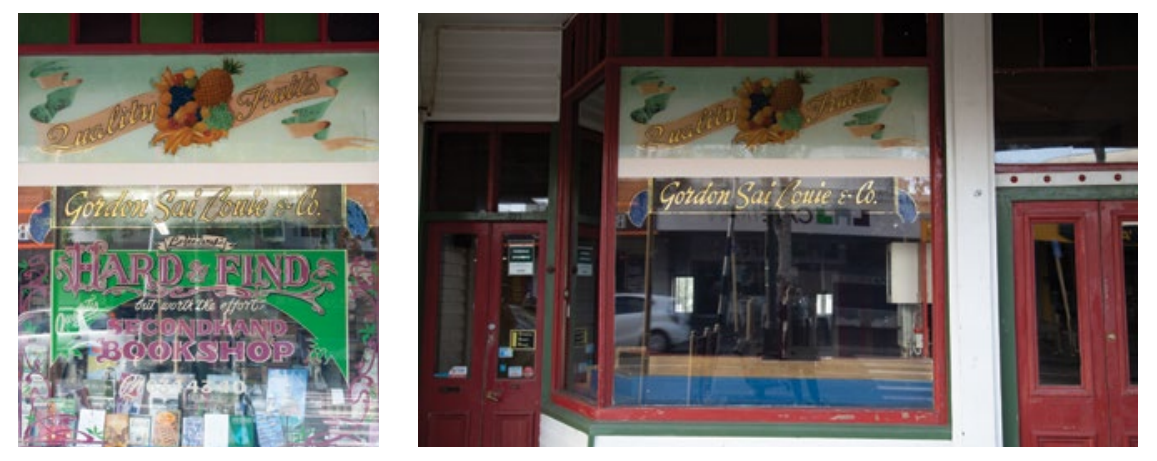

7. Caroline Powley, Sai Louie window, 2018, Rishworth building, 171 Onehunga Mall, Auckland 8. Caroline Powley, Sai Louie window, 2020, Rishworth building, 171 Onehunga Mall, Auckland.

Some signs may strike it lucky with their new owners. When I asked Warwick Jordan, owner of the Hard to Find Bookstore in Onehunga why he kept the vintage fruit store sign on the front window of his business, he said, "I think it's wonderful, it wasn't even a decision." 36 This response is possible when there is a synergy between the business and the vintage sign. A second-hand bookstore has a clear relationship to notions of antiquity and the value of history. The Gordon Sai LouieQuality Fruits sign was painted sometime in the early 1940s and is one of only two remaining vintage fruit shop signs that I' $m$ aware of in Auckland. It is an aesthetically appealing link to both the prominent local Sai Louie family and the strong cultural heritage of Chinese family-based produce businesses across New Zealand. In this situation, the historic sign actively added character to the Bookstore premises and implies value on the repurposing of history.

However, this symbiotic relationship recently came to an end. In 2018 the Rishworth building changed hands and the Hard to Find Bookstore could not continue its lease. After 22 years Warwick and his books moved out and the additional hand-painted signage that promoted the Hard to Find Bookstore was scraped off the glass window. Warwick was concerned about what new owners of the building might have planned for the building and the vintage fruit shop signage. "It's very valuable and has got to be kept", he said, emphasising the way it reflected "the core nature of Onehunga" ${ }^{37}$ and connected the site to "an important Onehunga family." Fortunately, the Auckland Unitary Plan Heritage Schedule has listed the Rishworth's Building under Category B, through the historical, social, physical attributes, aesthetic and context criteria. ${ }^{38}$

HERE-REPAIR

One response to environmental wear and tear on a historic sign is to repair it. This can vary in scale from ongoing minor fixes through to fullscale overpainting.
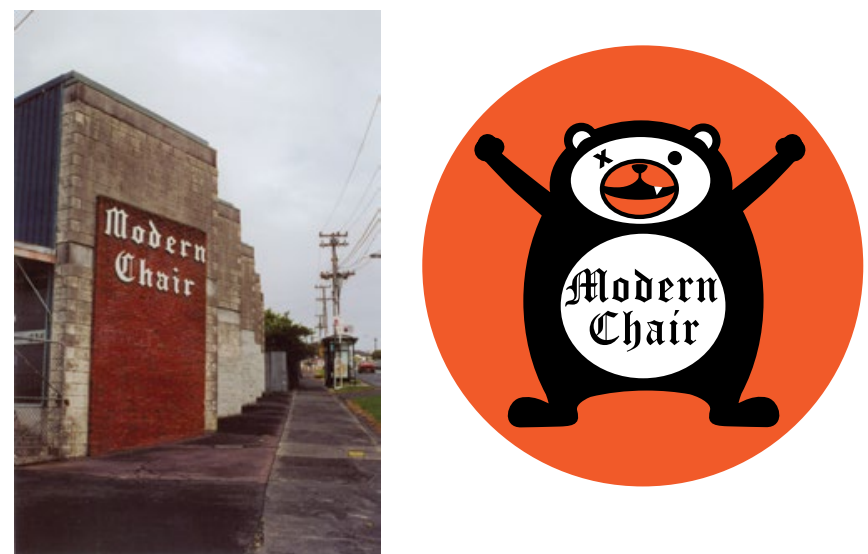

9. Caroline Powley, Modern Chair sign, 2004, 238 Richardson Rd, Auckland. 10. Jane Westaway (Westawaylnk), Modern Chair logo, 2014, Auckland.

Modern Chair has been designing and manufacturing furniture since 1912 and the typographic sign was moved to its Mt Roskill site in 1962. I've seen the sign in various states of disrepair-missing letters or suffering from graffiti, but it is always returned to its former Old English glory. Andrew Riley, who worked at Modern Chair, says the sign is "like the one on Fawlty Towers-you go out and there's a letter dangling down." ${ }^{39}$ Since the sign is part of the "family history and the story of the company" Andrew says they will continue to "repair it as long as the business is going." 40 In addition to the historical value to the company, it also forms a part of their brand. The company does not have a website, largely picking up new customers through word of mouth. Andrew says that "people will see it and go "I know that place!" "41 The community value of a distinctive local sign has been demonstrated through a 
local band's appropriation of the 'Modern Chair' name. Their t-shirts prominently feature a version of the sign as the branding for their band. Andrew from the Modern Chair furniture business doesn't see this as a conflict of interest, instead viewing it as an indication of the affection for the sign within the local community. ${ }^{42}$
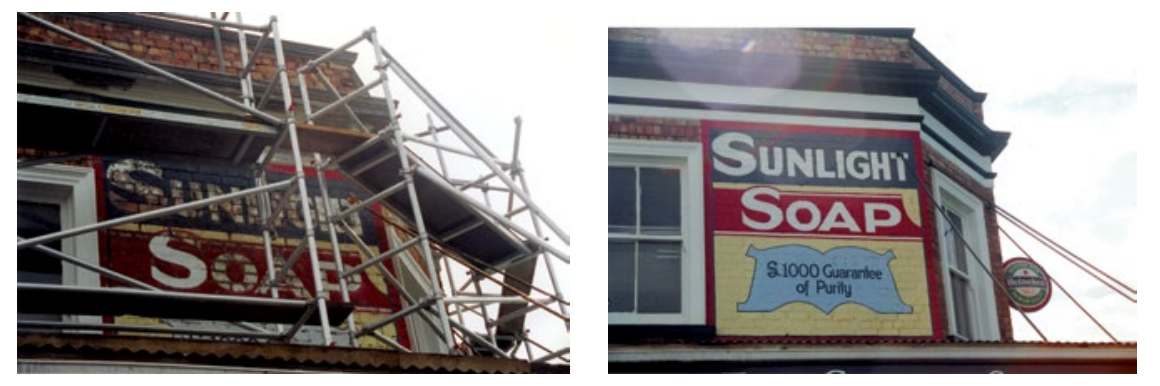

11. Caroline Powley, Sunlight Soap sign, 2004, 25 Mt Eden Rd, Auckland.

12. Caroline Powley, Sunlight Soap sign, 2004, 25 Mt Eden Rd, Auckland.

The ongoing maintenance of the Modern Chair sign is prompted by its value to a functioning business. The repair of an eroded sign that no longer has any active promotional purpose needs to be motivated by other perceived benefits. The opportunity to exploit the recognition value and play upon the public's fondness for an old sign often makes keeping historic signs a good marketing strategy. ${ }^{43}$ The 'Sunlight Soap' sign in Uptown Auckland was probably created in the late 1920s and was repaired in 2004. During the repair process, the signwriter told me that a new building owner had chosen to spend the money to repaint the sign. ${ }^{44}$ Historic signs are increasingly being conserved as part of the building's 'character', which can have both aesthetic and commercial benefits. ${ }^{45}$ It is no longer about selling Sunlight Soap, but instead it becomes about creating an aura of authenticity that imbues value on the bar now running out of the building.

Overpainting a faded painted sign can prompt both positive and negative reactions. Some could be happy to see a piece of the past come back to life and gain some insight into "how striking these advertisements would have been when they were fresh and young." 46 Dissenting voices would bemoan the destruction of the original sign's integrity and authenticity. The patina of age often forms a large part of the aesthetic appeal of a historic sign, while also signifying continuity, loss and survival. A more cynical viewer could also frame it as the commercially-based appropriation of the past, and question the superficiality of reapplying paint to a no longer active sign. ${ }^{47}$ Repainting may also remove the possibility of heritage scheduling, as the criteria usually considers the level of integrity and originality of an object when assessing its significance. If an object is scheduled, the Auckland Council requires all repairs to be carried out in a manner and design and with similar materials and appearance to those originally used. ${ }^{48}$ A quality restoration requires research and hiring a signwriter with the requisite skills and lightness of touch to replicate the qualities of a historic sign. This dissonance between preservation and authenticity is part of what makes the protection and conservation of historic signs problematic.

\section{TRACE-REGENERATE}

Rather than repair a vintage sign through repainting, there are examples where the business has decided to regenerate the original signage through more contemporary materials.
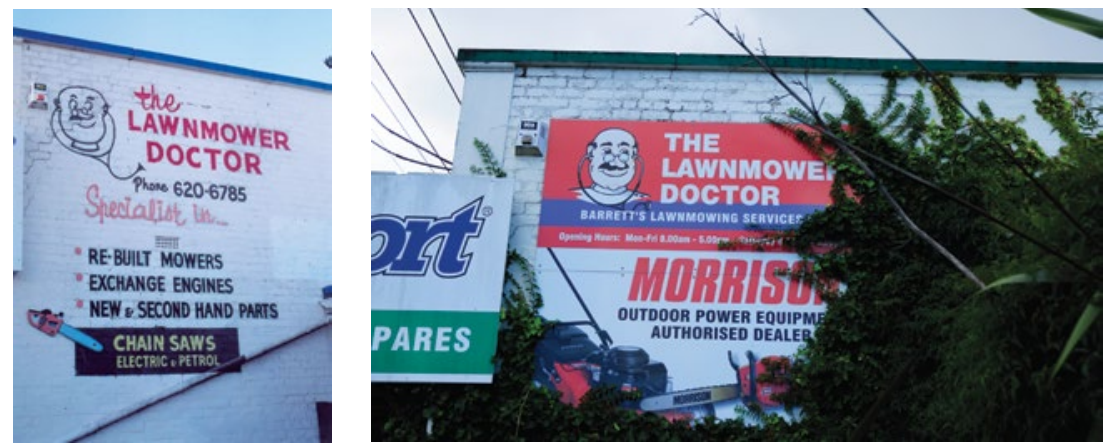

13. Caroline Powley, Lawnmower Doctor sign, 2004, 956 Dominion Rd, Auckland

14. Caroline Powley, Lawnmower Doctor sign, 2018, 956 Dominion Rd, Auckland.

When I first started documenting local signs in 2004 I spoke to the owner of Barrett's Lawnmowing Services, commonly known as 'The Lawnmower Doctor'. He recalled how this memorable name and visual identity had been developed for his business by a local signwriter. ${ }^{49}$ Several years later I noticed that the hand-painted signage had been covered with digitally created and printed sign boards. The new design clearly referred to the previous historic sign by including an updated version of the 'Lawnmower Doctor' icon. While this regenerated design was clearly not trying to entirely replicate the original historic signage, they were probably aware of the brand value held by the 'Lawnmower Doctor' image. This was a small local business, whose visual identity 
was generated by its store signage - the digitally produced signs represent an evolution of that brand. I may pine for the irregular type that used bricks as a baseline grid, but I was also happy to see the 'Lawnmower Doctor' live on in some form.
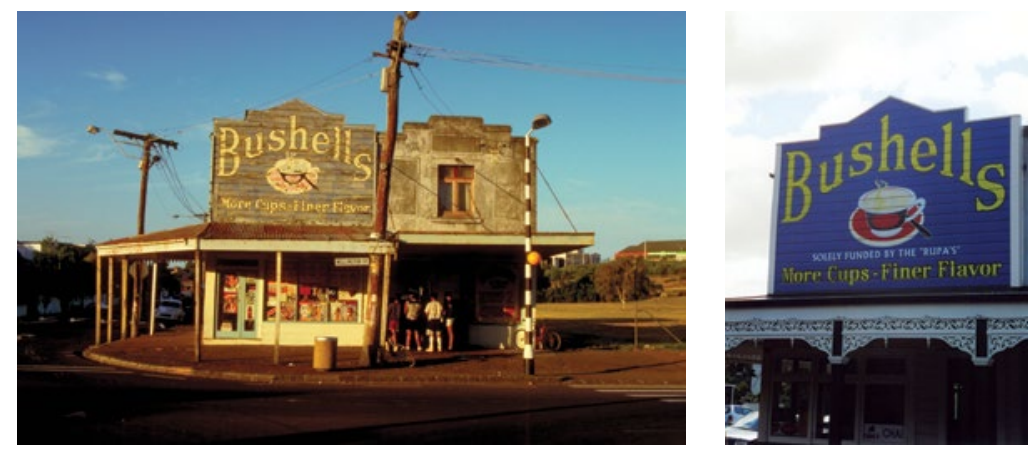

15. Robin Morrison, Wellington St. Dairy, 1980, 103 Wellington St, Auckland. ๑ All rights reserved, Auckland Museum-PH-NEG-RMX214 $\quad$ 16. Caroline Powley, Bushells sign, 2004, 103 Wellington St, Auckland.

Attempting to regenerate an iconic historic sign can present a serious risk for the business owners involved. When a sign is a local landmark, the surrounding community may feel a sense of shared ownership and can become quite vehement in their opinions about what changes should be made. The Rupa family who owned a small grocery store in Freemans Bay fell foul of both local residents and Auckland Council in 2001 when they removed the historic Bushell's tea sign above their premises. They had been granted permission to repair the original late 1940s era sign. Instead they 'solely funded' a signwriter to create a new, reimagined version of the signage. Auckland Council served Dilip Rupa with an abatement notice "giving him four weeks to remove the wording 'solely funded by the Rupas', or risk prosecution under the Resource Management Act." 50 Mr Rupa thought "the council should concentrate on the bigger issues" ${ }^{51}$ and did not make any changes to the sign.

\section{TRACE-RELOCATE}

When confronted with the possibility of losing an iconic sign, people often suggest donating it to a museum. This is not as simple a solution as it sounds - there are only a few public institutions that actively collect any form of graphic design. The Auckland Central Library has an extensive collection of design ephemera, but focusses on works on paper and the Auckland War Memorial museum has a limited remit for collecting large commercial artefacts. Small local museums do sometimes include signage in their collections and there are several individual historic sign collectors active in Auckland.

While any of these options would be preferable to a sign of heritage significance being destroyed, there are costs associated with removing the sign from its original context. The pragmatic cost of removing, transporting and installing signage requires funding. However, the more significant cost is to the cultural significance of the sign itself. They need an on-going association with their original location in order to maintain their authenticity and integrity. Relocating a historic sign to another site dislocates it from the rich social, commercial and community histories of its local environment.
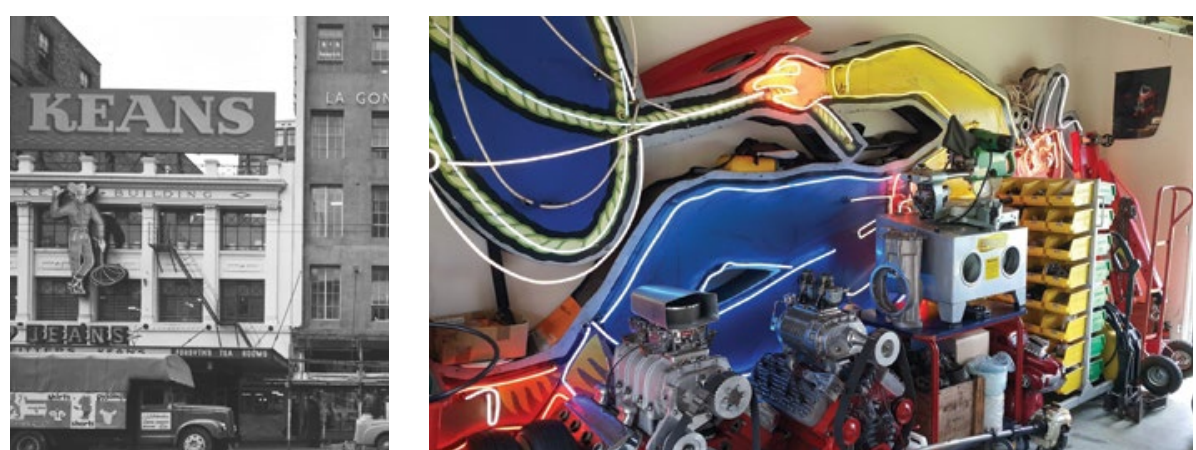

17. Clinton Firth, Neon Cowboy sign (Auckland), 152 Queen St, Auckland. @ All rights reserved, Sir George Grey Special Collection, Auckland Libraries - 34-R493B. 18. Chris Peacock, Neon Cowboy sign (Wellington), 2017, Auckland. ( A All rights reserved, Chris Peacock.

In the 1960s, Queen Street was home to the 'Neon Cowboy'. The original single-sided cowboy swung an animated lariat outside the 'Keans for Jeans' store. ${ }^{52}$ At some point, he was replaced with a doublesided version and in the 1980s he moved to a new location outside Armadillo's Mexican restaurant on Symonds St. ${ }^{53}$ This was an instance where there was an opportunity to 'send it to the museum'. Claude Neon, the company that created the sign, reportedly offered to cover the costs of moving the sign to the Auckland Museum, as well as maintain the sign. Unfortunately, the Neon Cowboy never found his way there. Instead he was separated into two sides, with one half allegedly coming to the end of his journey in a fire that claimed an art collector's home. ${ }^{54}$ Wellington's iteration of the Neon Cowboy made his way up the country on the back of a ute and now resides in a signage collection, based just north of Auckland. ${ }^{55}$ 

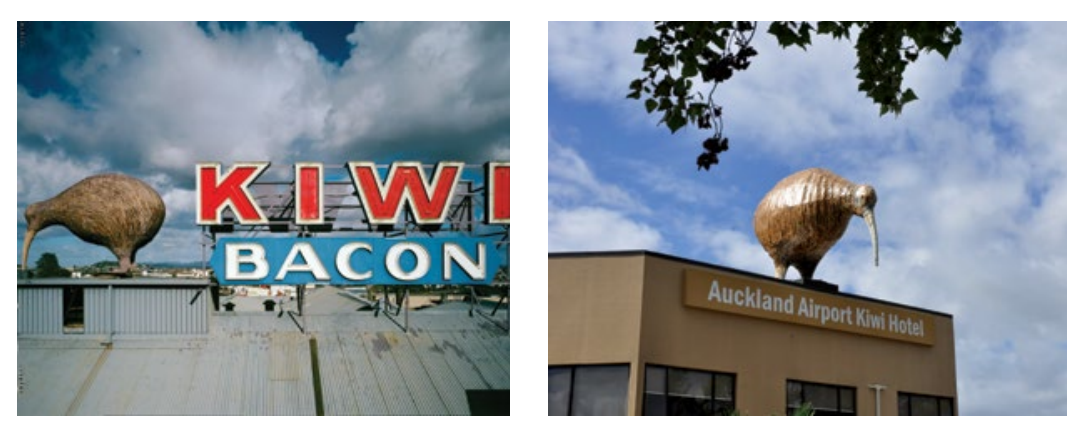

19. Geoffrey H. Short, Kiwi Bacon, 1988, 317-319 New North Rd, Auckland. (c) All rights reserved, Geoffrey H. Short.

20. Caroline Powley, Kiwi sign, 2018, Auckland Airport Kiwi Hotel

150 McKenzie Rd, Auckland.

The roof of the Kiwi Bacon factory in Kingsland used to be home to a large, three-dimensional, rotating kiwi. When the factory closed there was much public concern and speculation about finding it a new home. ${ }^{56}$ The two metre, two tonne kiwi managed to squeeze its way through the doors of the Auckland Museum, but only for a short stay. After featuring prominently in the Kiwiana exhibition curated by Richard Wolfe in 1990, the sign was returned to its owner, Claude Neon. Then in 1992, the giant fibreglass kiwi was painted gold and relocated to its current home on the rooftop of the Auckland Airport Hotel in Māngere. ${ }^{57}$ This historic sign made the transition from a brand icon for Kiwi Bacon company to signifying the national brand of New Zealand. The kiwi was lucky to have the opportunity of a second life, many other historic signs are not so adaptable.

\section{GONE-REPLACE}

Commercial signage is subject to changing circumstances, trends and values. The following two historic signs were replaced, despite the businesses they advertised continuing to operate. The signs were not fading or structurally unsound. Rather their replacement reflects a slippage in their perceived value.

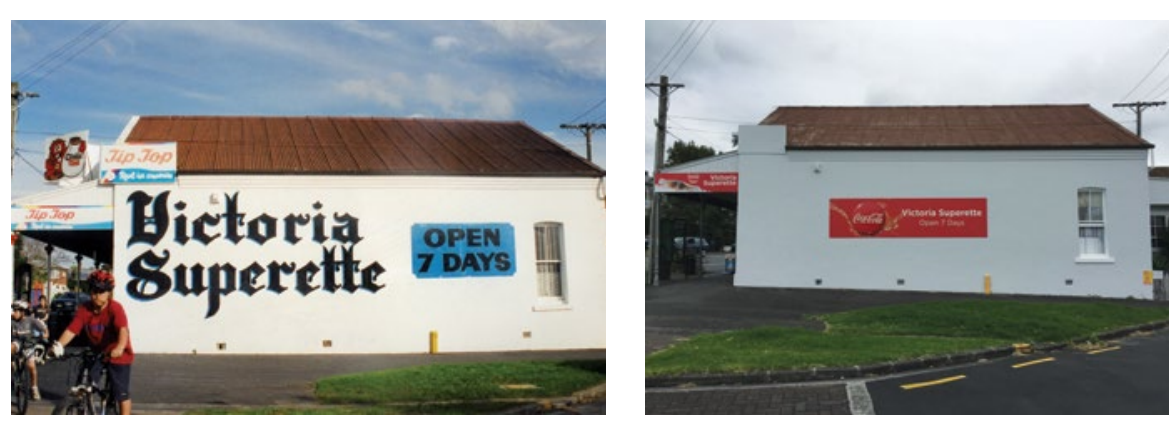

21. Caroline Powley, Victoria Superette sign, 2004, 165 Victoria Rd, Auckland. 22. Caroline Powley, Victoria Superette sign, 2018, 165 Victoria Rd, Auckland.

The bold and idiosyncratic statement that was the historic Victoria Superette sign has been replaced with a thoroughly generic branded board sign. What could motivate a business owner to replace a distinctive piece of local signage with something reflecting the brand guidelines of the Coca Cola company? The funding of dairy shop signage by Coke and various milk companies has largely obliterated the individual nature of our local dairy signage. To me this feels like an extension of the homogenisation of our retail environments, where the same set of retail chains appear in each shopping area. In some situations, small business owners may need access to funding in order to conserve a historic sign and retain their individual voice.

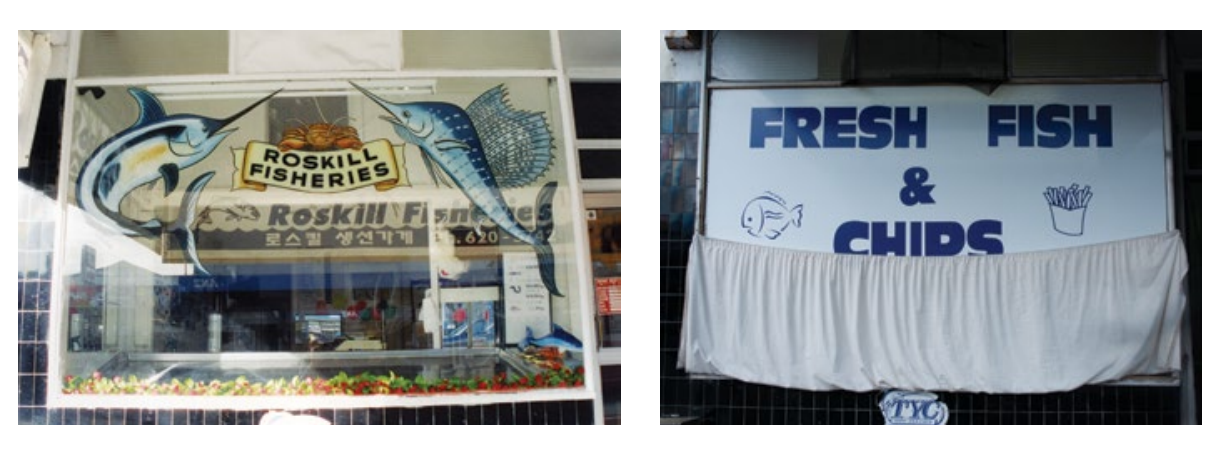

23. Caroline Powley, Roskill Fisheries sign, 2004, 1256 Dominion Rd, Auckland. 24. Caroline Powley, Roskill Fisheries sign, 2018, 1256 Dominion Rd, Auckland.

Fish shop windows were once a visual feast, displaying some of the most technically accomplished hand-painted signage in town. Over the last few decades many of Auckland's fish shops have closed, reflecting a change in shopping habits. As consumers moved towards the one stop supermarket shopping, rather than visiting a range of specialist food stores. The highest quality fish shop sign left in Auckland was in the 
window of Roskill Fisheries. When I drove past and saw that new owners had replaced with a clunky piece of vinyl signage, I was devastated. This loss demonstrates the need to schedule historic signs in their own right, independent of the heritage value of the associated building. This could mean there is someone to advocate for the long-term conservation of their cultural significance.

GONE-REMOVE

Given all the forces conspiring against commercial signage, it can seem like sheer good fortune that any examples last long enough to be considered historic. Baudrillard (1968, p.83) suggests that "In the last reckoning every antique is beautiful merely because it has survived, and thus become the sign of an earlier life". ${ }^{58}$

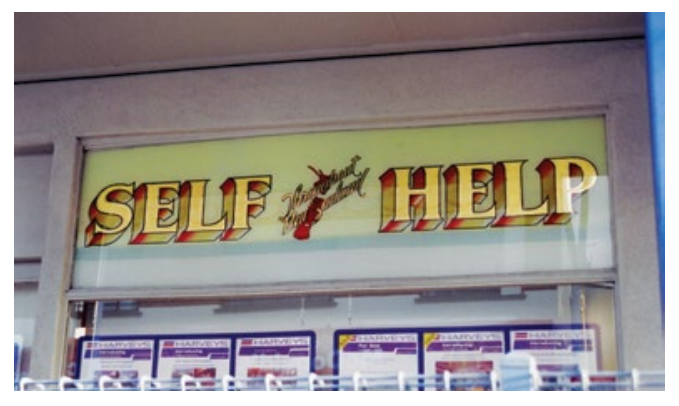

25. Caroline Powley, Self Help sign, 2004, 719

Mt Albert Rd, Auckland.

The 'Self Help' sign in Royal Oak was one of my favourite historic signs in Auckland. Gilded glass typography, with shaded 3D serif all-capswhat was there not to like? The 'Self Help' does not refer to new-age psychology, but is instead the brand name of a long-gone chain of grocery stores. Self-Help was New Zealand's early manifestation of the supermarket-a co-operatively owned 'groceratia' where customers 'helped' themselves by selecting and/or wrapping their own groceries. This was a sea-change for consumer experience-a move from the traditional process of being served individually by a grocer, who would select and wrap your groceries for you. ${ }^{59}$ As far as I'm aware the Royal Oak signs were the last two remaining Self-Help signs in the country. Unfortunately, they have since been scraped off to make way for frosted film. This represents not only an aesthetic loss, but also the removal of cultural significance.

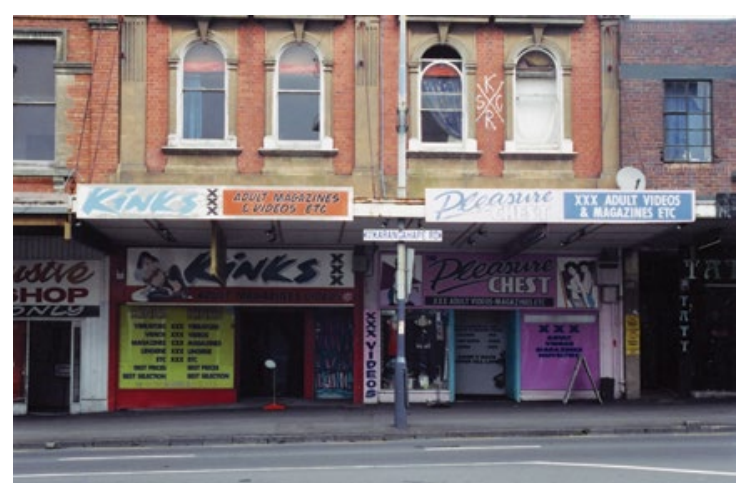

26. Caroline Powley, Pleasure Chest \& Kinks signs, 2004, 464466 Karangahape Rd, Auckland.

Karangahape Road is one of the oldest roads in Auckland and has experienced a series of transformations. ${ }^{60}$ Its history begins as an early Māori travel route, was commercially developed from the 1860s, hits a shopping heyday in the 1960s, has a motorway cut it in half, embraces the adult industry and then transforms into the 'gritty', 'edgy', 'colourful' and 'quirky' 61 place that is loved by many today. The road is now moving into the next phase of renewal with the Karangahape Road Plan 20142044. The wider area is scheduled as Category B through the Auckland Council's Historic Heritage Schedule as the Karangahape Road Heritage Area and the 2014-2044 Plan says it is "hugely important to do all of this while protecting and enhancing Karangahape Road's historic heritage, unique cultural identity, and the 'gritty' character."62 A comment in the Karangahape Road Streetscapes Improvement Project online feedback summary acknowledges the role historic signs play in the character of the area, "I particularly like the various old signage along the road... It would be a real shame to lose these things that give a visual history... to the place." ${ }^{63}$ Karangahape Road has now lost every single one of its original sex shops ${ }^{64}$ and all the associated signage. The Pleasure Chest building was renovated in 2015 and the sign was sold for $\$ 2662$ on Trade Me..$^{65}$ The slightly worse-for-wear Vegas Girl is now the last girl standing (or perhaps lounging) on Karangahape Road. She is the only remaining historic sign to clearly signify the area's previous life as a red-light district. She is mentioned in the 2014 draft evaluation of the Karangahape Road Heritage Area. It suggests that, "it is possible for the façade to be restored to a more original appearance"66, which may indicate an interest in repainting the fading glamour of the Vegas Girl. 


\section{ARCHIVE-RECORD}

My twelve case studies present a diverse range of outcomes for historic commercial signage and identify associated heritage management issues. Given that historic signs are subject to much change, it seems useful to consider alternatives when conservation is not possible. Internationally there are a number of digital archives that document examples of historic signage. These range from individual amateur collections, through to collaborative community crowdsourcing and the professional archives of heritage organisations.

The value of even a straightforward photographic archive is made apparent by looking at a local example; Mark Spurgeon's Preserve website. It largely consists of photographs of pre-quake Christchurch signage, much of which has now been destroyed. The documentation of these signs now forms a resource for researchers and residents wanting to recall the cityscape before the earthquake. However, a solely photographic archive can offer only basic insight into a sign's broader social, historic and cultural context. A survey on Sam Roberts' Ghostsigns project identified that the "full meaning and value was only realised when people were told stories about the signs." 67

Ghostsigns started out as an amateur-led collection that used crowd-sourcing to photograph, research, and digitally archive a large number of 'ghost signs' in the United Kingdom. ${ }^{68}$ Project founder Sam Roberts then collaborated with History of Advertising Trust to embed it within the institution, as part of its remit to "preserve and protect the heritage of UK advertising history". ${ }^{69}$ There has been some debate about the ability of an amateur to gather and systematically organise a diverse range of rich content around the history and significance of a sign. However, digital culture researcher Laura Carletti thinks, "The Ghostsigns project is a pioneering example of 'history-from-below' and represents a rare example of crossover between grassroots and organisationally-driven digital preservation initiatives."70

INTERNATIONAL HERITAGE

Internationally, both the UK and Australia have a similar model to New Zealand, in that heritage management is largely executed through local authorities. When questioned about the lack of active conservation for historic signs, a UK MP suggested that a 'ghost signs' charm came from "the fact that such things survive only rarely and accidentally" and that, "although their loss may be regretted, perhaps it is necessary to allow such changes to happen, untouched by a regulatory framework." 71 In contrast, the Australian state of New South Wales published Rachael Jackson and Caroline Lawrance's Conserving Historic Signs Guidelines. This document is the first time that the Australian heritage sector tried to respond to the specific issues relating to painted signs. ${ }^{72}$ It outlines criteria for the assessment of significance and unpacks a range of conservation approaches, while also promoting the scheduling of signage as a heritage item in its own right, independent of the associated architecture. ${ }^{73}$ Also in Australia, Heritage Victoria and the City of Yarra jointly commissioned a study of historic illuminated signs. In addition to identifying and reviewing the heritage importance of this type of sign, the study also explores management issues, retention strategies and funding options for conservation. Both the National Trust of Australia (NSW) Register and the Victorian Heritage Register include a number of historic signs as stand-alone items in their scheduling lists. Heritage advisor Leisa Clements believes that the NSW guidelines could "easily be incorporated into new frameworks, or adapted by heritage agencies and practitioners." 74 There are also ideas to be gleaned from other specifically sign-focussed international examples, such as the U.S. Department of the Interior National Park Service-Preservation Briefs 25-The Preservation of Historic Signs.

\section{CONCLUSION}

Given the fast pace of commercial change in Auckland, it's not surprising that we don't have a lot of historic signs left in situ. This emphasises not only the fragility of this form of heritage, but also the significance of the rare survivors. ${ }^{75}$ Heritage practice involves a fine balance between allowing room for progress, while also celebrating and conserving our shared histories and values. As Lewis and Wright suggest, "It is not only impractical but impossible for everything that evidences us to survive." 76 However, this logic does not diminish the stab of sorrow I feel whenever I drive past a favourite sign and see that it's gone. Glenn Albrecht's idea of Solastalgia describes this sense of loss as, "the erosion of the sense of belonging (identity) to a particular place and a feeling of distress... about its transformation."77 I'm not suggesting that all of the signs included in this paper should have been conserved. More that historic signs need specific consideration within our current heritage management systems in New Zealand. In the meantime, there is a joy to be had in the hunting out of historic signs keep an eye out for what you can find and celebrate their survival. 


\section{REFERENCES}

Albrecht, Glenn. "'Solastalgia': A New Concept in Health and Identity." Philosophy Activism Nature, no. 3 (2005): 41-55, Informit.

Auer, Michael J. Preservation Briefs 25: The Preservation of Historic Signs. Washington D.C.: U.S. Department of the Interior Nationa Park Service Cultural Resources, 1991, 2532. www.nps.gov/tps/how-to-preserve/ preservedocs/preservation-briefs/25PreserveBrief-Signs.pdf

Baines, Phil, and Catherine Dixon.

Signs: lettering in the environment. London: Laurence King, 2003

Baudrillard, Jean. System of Objects. London: Verso, 1996

Carletti, Laura. "Crowdsourcing Pioneers: The Co-creation and Institutionalisation of an Amateur Collection In Advertising and Public Memory: Social, Cultural and Historical Perspectives on Ghost Signs, edited Stefan Schutt, et al., 64-75. London: Taylor \& Francis Group, 2016. ProQuest Ebook Central.

Clement, Leisa. "Signs of Life: Recognising the Significance of Melbourne's Historic Painted Signs." In Advertising and Public Memory: Social, Cultural and Historical Perspectives on Ghost Signs, edited Stefan Schutt, et al., 225236. London: Taylor \& Francis Group, 2016. ProQuest Ebook Central.

Heritage New Zealand Poutere Taonga. "About the List Rārangi Körero." https://www.heritage. org.nz/the-list/about-the-list [accessed February 4, 2020]

Heritage New Zealand Poutere Taonga. "Strong's Watchmaker Shop." https:// www.heritage.org.nz/the-list/about-the-list [accessed February 4, 2020].

Huyssen, Andreas. Present Pasts: Urban Palimpsests and the Politics of Memory.
Stanford: Stanford University Press, 2003

International Council on Monuments and Sites (ICOMOS). ICOMOS New Zealand Charter for the Conservation of Places of Cultural Heritage Value. Auckland: ICOMOS, 2010. https:// icomos.org.nz/wp-content/uploads/2016/08/ NZ_Charter.pdf

Kwok, Brian Sze-Hang, and Anneke Coppoolse. "Illuminography: a survey of the pictorial language of Hong Kong's neon signs." Visible Language 51, no 1 (April, 2017): 88-111. http://visiblelanguagejournal.com/issue/242/ article/1622

ewis, Antonina, and Kirsten Wright. "Torch Songs to Modernity: Ghost Signs as Emblems of the Urban Soul." In Advertising and Public Memory: Social, Cultural and Historical

Perspectives on Ghost Signs, edited Stefan

Schutt, et al., 53-63. London: Taylor \& Francis Group, 2016.

Love, Anthony W. "The Ghost in the Sign: A Psychological Perspective on Ghost Signs." In Advertising and Public Memory: Social, Cultural and Historical Perspectives on Ghost Signs, edited Stefan Schutt, et al., 41-52. London:

Taylor \& Francis Group, 2016. ProQuest Ebook Central.

Mathur, Gaurav. "Signboards as Mirrors of Cultural Change." Design Issues 21, no. 4 (Autumn, 2005): 78-93, www.jstor.org/ stable/25224021

Ministry for Culture and Heritage. Heritage New Zealand Poutere Taonga Act. Wellington: New Zealand Government, 2014. http://www. legislation.govt.nz/act/public/2014/0026/latest/ DLM4005511.html

Roberts, Sam. "Ghostsigns: saving our hand painted advertising." The Ephemerist 148 (Spring 2010): 14-19. http://www.ghostsigns
co.uk/wp-content/uploads/2011/05/Ghostsignsin-the-Ephemerist-Spring-2010.pdf

Samuel, Raphael. Theatres of Memory: Past and Present in Contemporary Culture. London: Verso, 1994

Schutt, Stefan, and Sam Roberts. "A Final Ghost Story." In Advertising and Public Memory: Social, Cultural and Historical Perspectives on Ghost Signs, edited Stefan Schutt, et al. 288-292. London: Taylor 8 Francis Group, 2016. ProQuest Ebook Central.

Sinfield, David. "The Semiotics of Business Signage: How Typography is Used in Impoverished and Deprived Areas of New Zealand." The International Journal of the Image 4 no. 4 (2014): page range. http://dx.do org/10.18848/2154-8560/CGP/v04i04/4414

Trapeznik, Alexander, and Gavin McLean. "Public history, heritage and place." In Common ground?: heritage and public places in New Zealand, edited Alexander Trapeznik, page range. Dunedin, N.Z.: University of Otago Press, 2000

White, Leanne, and Stefan Schutt, and Sam Roberts. "Uncovering Ghost Signs and Their Meanings" In Advertising and Public Memory: Social, Cultural and Historical Perspectives on Ghost Signs, edited Stefan Schutt, et al., 12-24. London: Taylor \& Francis Group, 2016. ProQuest Ebook Central.

Statistics New Zealand. "Digital Yearbook Collection." (1893-2010). http://www.stats. govt.nz/browse_for_stats/snapshots-of-nz/ digital-yearbook-collection.aspx [accessed January 30, 2015].

Heritage Alliance. Historic Electric Signage in Victoria: A Study of Historic ilu Signs. Yarra, 2002. http://images.heritage.vic.gov.au/ attachment/47207.

\section{END NOTES}

1. Antonina Lewis and Kirsten Wright, "Torch Songs to Modernity: Ghost Signs as "Emblems of the Urban Soul," in Advertising and Public Memory: Social, Cultural and Historical Perspectives on Ghost Signs, ed. Stefan Schutt, et al., 54. London: Taylor \& Francis, 2016

Michael J. Auer, Preservation Briefs 25 The Preservation of Historic Signs (Washington D.C.: U.S. Department of the Interior National Park Service Cultural Resources, 1991), 6. www.nps gov/tps/how-to-preserve/ preservedocs/preservation-briefs/25Preserve Brief-Signs.pdf

3. Anthony W. Love, "The Ghost in the Sign A Psychological Perspective on Ghost Signs," in Advertising and Public Memory, 44.

. Gaurav Mathur, "Signboards as Mirrors of Cultural Change," Design Issues 21, no. 4 (Autumn, 2005): 80

Brian Sze-Hang Kwok and Anneke Coppoolse, "Illuminography: A Survey of the Pictorial Language of Hong Kong's Neon Signs," Visible Language 51, no 1 (April, 2017):

6. David Sinfield, "The Semiotics of Business Signage: How Typography is Used in Impoverished and Deprived Areas of New Zealand," The International Journal of the Image 4 no. 4 (2014): 26.

Phil Baines and Catherine Dixon, Signs: Lettering in the Environment (London: aurence King, 2003): 12.

Andreas Huyssen, Present Pasts: Urban Palimpsests and the Politics of Memory (Stanford: Stanford University Press, 2003)

9. Love, 42 
10. Ibid

11. Jean Baudrillard, System of Objects, (London: Verso, 1996): 76.

12. Sinfield, 25 .

13. Frank Jump, "About," Fading Ad, (blog), March, 2007, https://fadingad.wordpress.com/ about/

14. Raphael Samuel, Theatres of Memory: Past and Present in Contemporary Culture, (London: Verso, 1994): 205, quoted in Kayla Wilson, "The Art of the Achievable: An

Examination of Heritage Assessment Practice at the Department of Conservation," (master's thesis, Victoria University, 2013): 9, https:// researcharchive.vuw.ac.nz/xmlui/bitstream/ handle/10063/3103/thesis.pdf? sequence $=2$

15. Alexander Trapeznik and Gavin McLean, "Public History, Heritage and Place," in Common Ground?: Heritage and Public Places in New Zealand, ed. Alexander Trapeznik (Dunedin, N.Z.: University of Otago Press, 2000): 14 .

16. International Council on Monuments and Sites (ICOMOS), ICOMOS New Zealand Charter for the Conservation of Places of Cultural Heritage Value (Auckland: ICOMOS, 2010), 1, https://icomos.org.nz/wp-content/ uploads/2016/08/NZ_Charter.pdf

17. Tanya Sorrell, personal communication with author, November, 2020

18. Ministry for Culture and Heritage, Heritage New Zealand Poutere Taonga Act (Wellington: New Zealand Government, 2014), Part 2:13. http://www.legislation.govt.nz/act/ public/2014/0026/latest/DLM4005511.htm
20. Heritage New Zealand. "About the List Rārangi Kōrero," Heritage New Zealand

Poutere Taonga, accessed February 4, 2020, https://www.heritage.org.nz/the-list/aboutthe-list

21. Ministry for Culture and Heritage Heritage New Zealand Poutere Taonga Act (Wellington: New Zealand Government, 2014) Part 4:66. http://www.legislation.govt.nz/act/ public/2014/0026/latest/DLM5034913.htm

22. Heritage New Zealand Poutere Taonga, Application Guidelines for Historic Place and Historic Area entries on the New Zealand Heritage List/ Rārangi Kōrero (Heritage New Zealand Poutere Taonga, May 2014): 2-3 https://www.heritage.org.nz/the-list/ /link. aspx?_id=D39F7C252136451299EF7E983 4F4A55FG_Z=Z

23. Andrew Winter, telephone conversation with author, March, 2018.

24. "Strong's Watchmaker Shop," Heritage New Zealand Poutere Taonga, accessed April 18, 2018, https://www.heritage.org.nz/the-list/ details/2270

25. Ibid.

26. ICOMOS, 6-8

27. Nicola Short and Dr Frances Hancock "Ihumātao's Heritage Listing Win - What does it Mean?," The University of Auckland, February 28, 2020, https://www. auckland. ac.nz/en/news/2020/02/28/ihumatao-heritagelisting-win-what-does-it-mean.html

28. Auckland Council, Auckland Unitary Plan Operative in Part:Regional Policy Statement (Auckland: Auckland Council, 2016), 86, Updated 12 June 2020, Https:// unitaryplan.aucklandcouncil.govt.nz/
images/Auckland\%20Unitary\%20Plan\%20 Operative/Chapter\%20B\%20RPS/B5\%20 Historic\%heritage $\% 20$ and $\% \% 20$ special $\% 20$ character.pdf

29. Auckland Council, Guidelines for Nominating a Historic Heritage Place for Evaluation (Auckland: Auckland Council 2014), 3, https://www.aucklandcouncil.govt. nz/arts-culture-heritage/heritage/protectingour-heritage/docsnominationguidelines/ guidelines-nominating-historic-heritage-place.

30. Tanya Sorrell, telephone conversation with author, February, 2018.

31. Ibid

32. AkL, "Milan Mrkusich's public art," Heritage et $A L$, (blog), posted October 10, 2016, http://heritageetal.blogspot. com/2016/10/milan-mrkusichs-public-art.htm

33. Ibid.

34. Auckland Council, Auckland Unitary Plan Operative in part: Schedule 14.1 Schedule of Historic Heritage (Auckland: Auckland Council, 2016), 86, Updated 12 June 2020, https:// unitaryplan.aucklandcouncil.govt.nz/Images/ Auckland\%20Unitary\%20Plan\%200perative/ Chapter\%20L\%20Schedules/Schedule\%20 $14.1 \% 20$ Schedule $\% 20$ of\%20Historic\%20 Heritage.pdf

35. Auckland Council, Auckland Unitary Plan Operative in part: D17.2 Historic Heritage Overlay (Auckland: Auckland Council, 2016), 4, Updated 12 June 2020, https:// unitaryplan.aucklandcouncil.govt.nz/Images/ Auckland\%20Unitary\%20Plan\%200perative/ Chapter\%20D\%20Overlays/3.\%20Built\%20

Heritage $\% 20$ and $\% 20$ Character/D17\%20 Historic\%20Heritage $\% 200$ verlay.pdf
36. Warwick Jordan, telephone conversation with author, February, 2018

37. Ibid

38. Auckland Council, Auckland Unitary Plan Operative in part: Schedule 14.1 Schedule of Historic Heritage (Auckland: Auckland Council, 2016), 89, Updated 12 June 2020, https:// unitaryplan.aucklandcouncil.govt.nz/lmages/ Auckland\%20Unitary\%20Plan\%200perative/ Chapter $\% 20$ L $\% 20$ Schedules/Schedule $\% 20$ $14.1 \% 20$ Schedule $\% 20$ of $\% 20$ Historic $\% 20$ Heritage.pdf

39. Andrew Riley, telephone conversation with author, March, 2018.

40. Ibid

41. Ibid

2. Ibid.

43. Auer, 9

4. Signwriter, in conversation with author, 2004.

45. Leanne White, Stefan Schutt, and Sam Roberts, "Uncovering Ghost Signs and Their Meanings," in Advertising and Public Memory

6. Sam Roberts, "Ghostsigns: Saving our Hand Painted Advertising," The Ephemerist, no. 148 (Spring 2010): 18 http://www.ghostsigns.co.uk/wp-content/ uploads/2011/05/Ghostsigns-in-theEphemerist-Spring-2010.pdf

7. White, Schutt and Roberts, 13; Roberts, 


\section{END NOTES}

48. Auckland Council, City of AucklandDistrict Plan Central Area: Section 10.9.10.1

49. Business Owner, telephone conversatio with author, July 2004

50. Rebecca Walsh, "Rescuer Bagged over Tea Sign," The New Zealand Herald, July 24, 2001, https://www.nzherald.co.nz/nz/news/ article.cfm?c_id=1\&objectid=201790

51. Ibid

52. Blair French (@sign_guy_nz), “Here's a few photos I've found of the famous old keans jeans cowboy or cowboys I should say, there originally was a single sided neon cowboy on the front of the," Instagram pos July 12,2017 , https://www.instagram.com/p BWcb0TLDt4p/

53. Jonathan Ganley, "The Rise \& Fall of a Neon Cowboy: Symonds St 1992," Point That Thing, (blog), last modified September 13, 2009, http://www.pointthatthing com/2009/09/rise-fall-of-neon-cowboysymonds-st.html

54. Kim Knight, "Saving our Neon Heritage, Stuff, November 09, 2014, http://www.stuff. co.nz/national/10716411/Saving-our-neonheritage

55. Scott, July 22, 2014, comment on "So long, Cowboy," WellUrban (blog), https:/l wellurban.blogspot.com/2007/07/so-longcowboy.html?fbclid=IwAR2MmY7httw 19JbCZU5MvdNZpb_Y3z7Com0E_rfcFRss8ool74JVXRXOKO\#c543077128717482844

56. Auckland Star (Auckland), "Giant Kiwi Scratches for Nest," November 10, 1988: A 4
57. Māngere-Ōtāhuhu Local Board,

"Flashback Friday: Giant golden kiwi,

Mangere, 1992," Facebook, May 20, 2016 https://www.facebook.com/mangereotahuhu/ photos/a.154400234638709/10455768288 54374

58. Baudrillard, 83.

59. Julie, "Self Help Groceteria: NZ shopping 90 years ago," Redicover, (blog), posted June 27, 2016, https://rediscover.co.nz/ self-help-groceterias-nz-shopping-90-yearsago/\#: :text=In\%20a\%20brave\%20retail\%20 move,they $\% 20$ did $\% 20$ by $\% 20$ the $\% 20$ thousands.

60. Ludo Campbell-Reid, "The K Road Project Insider: The Design Champion," Bike Auckland, November 11, 2019, https://www. bikeauckland.org.nz/the-k-road-projectinsider-the-design-champion/

61. "About," The Karangahape

dentity Project, 2020, https://www.

thekarangahapeidentityproject.org/about

62. Waitematā Local Board, The Karangahape Road Plan 2014-2044, (Auckland:

Auckland Council, 2013), 6, https://www. aucklandcouncil.govt.nz/plans-projectspolicies-reports-bylaws/our-plans-strategies/ place-based-plans/Documents/karangahape road-plan-2014-2044.pdf

63. Auckland Transport, Karangahape Road Streetscapes Improvement Project: Online Feedback Summary, (Auckland: Auckland Transport, 2016), 2, https://at.govt.nz/ media/1717104/k-road-online-feedback summary.pdf

64. Tina Plunkett, "Built heritage, special places and community cultures: it's up to you," Public Address, (blog), posted October 6, 2015, https://publicaddress.net/speaker/ built-heritage-special-places-and-community

65. New Zealand Herald, "Punters fork up for sex shop memorabilia," Herald on Sunday, 29 August, 2015, https://www.nzherald.co.nz/nz/ news/article.cfm?c_id=1\&objectid=11504960

66. Auckland Council Heritage Unit, Draft Historic Heritage Area Evaluation: Karangahape Road (K'Road) (Auckland: Auckland Council, January 2014), 83, https://www.kroad.com/ manage/resources/krd-evaluation-heritagefinal-1.pdf

67. Stefan Schutt and Sam Roberts, "A Final Ghost Story," in Advertising and Public Memory, 291.

68. Laura Carletti, "Crowdsourcing Pioneers The Co-creation and Institutionalisation of an Amateur Collection," in Advertising and Public Memory, 268.

69. Ibid.

70. Ibid

71. Roberts, 18

72. Leisa Clement, "Signs of Life Recognising the Significance of Melbourne's Historic Painted Signs," in Advertising and Public Memory, 232.

73. Ibid.

74. Ibid

75. Heritage Alliance, Ellwood Heritage Review, (Port Phillip: City of Port Phillip, 2005), 4, quoted in Leisa Clement, 230-231.
76. Antonina Lewis and Kirsten Wright, "Torch Songs to Modernity Ghost Signs as "Elems of the Urban Soul," in Advertising and Public Memory, 55

77. Glenn Albrecht, "'Solastalgia': A New Concept in Health and Identity," Philosophy Activism Nature, no. 3 (2005): 45. 